\title{
Spain and the Crisis: Housing Prices, Credit, and Macroprudential Policies
}

\author{
Margarita Rubio* \\ University of Nottingham
}

\author{
José A. Carrasco-Gallego ${ }^{\dagger}$ \\ University of Portsmouth
}

July 2015

\begin{abstract}
In this paper, we propose a two-country, two sector monetary union DSGE model with housing. One of the countries is calibrated to represent the Spanish economy while the other one is the rest of the European monetary union. First, we illustrate how looser credit conditions coming from the Euro area, together with increases in housing demand, lead to an increase in house prices and credit in Spain. Then, we analyze to what extent, macroprudential policies could have avoided the excess in credit that triggered the financial crisis in Spain. We find that a countercyclical loan-to-value rule that mainly responds to house prices would have mitigated the credit boom in Spain. These results can also be applied to other countries facing similar problems in the housing sector and thinking about implementing macroprudential policies.
\end{abstract}

Keywords: Housing boom, house prices, macroprudential policy, dynamic provisioning.

JEL Classification: E32, E44, E58

\footnotetext{
${ }^{*}$ University of Nottingham, Sir Clive Granger Building, University Park, Nottingham, NG7 2RD, UK. E-mail: margarita.rubio@nottingham.ac.uk

${ }^{\dagger}$ University of Portsmouth, Portsmouth Business School, Portland St, Portsmouth PO1 3DE, UK. E-mail: jose.carrascogallego@port.ac.uk
} 
"[...] Dynamic provisioning did make banks stronger than would otherwise have been the case, and there is some suggestive evidence that it moderated the credit boom as well. Whether the Bank of Spain's response was proportional to the challenge, or more should have been done, remains a matter of debate". Jaime Caruana, 2012.

\section{Introduction}

The recent crisis in Spain had its center in the housing sector. Easier borrowing conditions together with speculative housing demand gave rise to a housing bubble that burst, bringing a strong recession. Spain accession to the Euro area delivered unprecedented low interest rates, in part due to the good performance of its Euro partners. This, together with a strong housing demand, brought a house price and credit boom in Spain that was the seed of the crisis.

However, some macroprudential measures were taken by the Bank of Spain before the crisis in order to palliate this credit boom, namely the so-called dynamic provisioning. The effect of provisioning has been found to have had only a small impact on credit growth, while being useful in building up countercyclical buffers to strengthen the solvency of banks. While macroprudential measures seem to be effective as preventive tools, in this case, it did not seem to be enough to avoid the crisis.

In this paper, we propose a two-country, two-sector monetary union DSGE model with housing and collateral constraints, allowing for cross-country differences in mortgage and housing markets as well as asymmetric shocks. One of the countries is calibrated to represent the Spanish economy while the other one is the rest of the European monetary union.

First, we illustrate how looser credit conditions coming from the Euro area monetary policy and housing demand shocks lead to an increase in house prices and credit in Spain. Then, we analyze to what extent, an optimal implementation of macroprudential policies could have avoided the excess in credit that triggered the financial crisis in Spain. In particular, we analyze the implementation of a rule on the LTV ratio, as an alternative or a complement of the dynamic provisioning tool that was put in place. We propose an implementation of this macroprudential policy which is analogous to how monetary policy is conducted. We assume that the same way that the central bank follows a Taylor rule for monetary policy, the macroprudential authority also follows a linear rule to carry out the macroprudential policy, using the LTV as an instrument. The monetary policy literature has extensively shown that simple rules result in a good performance; therefore it seems sensible to apply this kind of rule to macroprudential 
supervision (See Yellen, 2010). ${ }^{1}$ We consider a rule for the LTV ratio which responds to deviations of credit from its steady state. In this way, booms that lead to an increase in borrowing are moderated. ${ }^{2}$

Even if the topic of dynamic provisioning and macroprudential tools in Spain has already been studied, it is the first time that it is studied in a DSGE framework. Furthermore, within this setting, we are able to provide optimal parameters for an LTV macroprudential tool as well as the welfare gain from introducing this measure. This is a novel and worthwhile contribution of our paper.

The basic modelling framework follows Rubio (2014), to which we add macroprudential measures. In each country, there is a group of individuals that are credit constrained and need housing collateral to obtain loans. Countries trade goods, and savers in each country have access to foreign assets. We obtain the optimal combination of LTV rule reaction parameters that maximizes welfare for Spain, given monetary policy.

This paper relates to different strands of the literature. The model constitutes a two-country, twosector version of the seminal paper of Iacoviello (2005), that introduces a financial accelerator that works through the housing sector, in the flavor of Aspachs and Rabanal (2010). However, it introduces cross-country housing-market heterogeneity as in Rubio (2014). This paper is also related to the recent literature on macroprudential and monetary policies in Iacoviello-type models such in the aforementioned Kannan, Rabanal and Scott (2012) or Rubio and Carrasco-Gallego (2014). However, the novelty of this paper is that it explores the issue for the specific case of Spain, one of the few countries in which some macroprudential policies have been already implemented before the crisis. The model is appropriately calibrated to reflect the basic features of the Spanish economy, that is, an LTV that is larger than the average, variable-rate mortgages, a 10\% relative size, and higher housing wealth to GDP.

Results show that low interest rates, coming either from a monetary policy shock or from a productivity shock in the Euro area, can explain the credit boom in Spain that preceded the crisis. However, this alone cannot account for the strong increase in house prices in this country. Loose credit conditions must be combined with a housing demand shock in order to explain both the credit boom and the increase in house prices. We also find that a macroprudential rule that decreases LTVs in booms would have moderated the credit boom. We find the optimal LTV rule that maximizes welfare for the Spanish

\footnotetext{
${ }^{1}$ We can find other examples of LTV rules in the literature. Funke and Paetz (2012) use a non-linear rule on the LTV and finds that it can help reduce the transmission of house price cycles to the real economy. In a similar way, Kannan, Rabanal and Scott (2012) examine a monetary policy rule that reacts to prices, output and changes in collateral values with a macroprudential instrument based on the LTV. Lambertini et al (2013) allow for the implementation of both interest-rate and LTV policies in a model with news shocks.

${ }^{2}$ The IMF (2013) states that a macroeconomic environment which gives rise to credit growth will contribute to the build-up of systemic risk.
} 
economy. These results can also be applied to other countries facing similar problems in the housing sector and thinking about implementing macroprudential policies.

The paper is organized as follows. Section 2 explains the Spanish experience before the crisis. Section 3 describes the model. Section 4 presents the simulations. Section 5 introduces the macroprudential policies. Section 6 concludes.

\section{The Spanish Experience}

After entering the Euro area and preceding the crisis, Spain experienced one of the most important housing booms among developed economies. This housing boom was one of the main engines for economic growth in Spain. ${ }^{3}$ The economies of different countries have been affected with different degrees of intensity according to their exposure to some of the main drivers of the financial crisis. The excessive dependence of the real estate industry, jointly with a softening of the credit standards and variable rate mortgages caused that economic and financial crisis hit Spain more severely than to other developed economies.

The introduction of the Euro eliminated intra-Euro Area currency risk and also led to a convergence of Spanish interest rates to the lower interest rates in the Euro zone. Before the launch of the Euro, Spanish nominal interest rates were markedly higher than the rest of Europe. The common currency led to a convergence of Spanish nominal rates to Euro Area rates. The average Spanish government interest rate (interest payments/sovereign debt stock) fell from around $9 \%$ in the late 1990s to below $4 \%$ by 2010 (See Figure A1 in the Appendix). In this paper, we proxy the convergence to lower interest rate by a negative interest-rate shock.

Furthermore, improvements in productivity in the big countries of the Euro area contributed to a lower interest rate, following the needs of the majority (See figure A2 in the Appendix). However, even though Spain's productivity was not improving, it benefitted from the lower interest rates stemming from a single monetary policy. In fact, according to In 't Veld et al. (2014), in Spain, the boom saw strong growth in the employment of unskilled labor that was also fuelled by immigration. Hence, average Spanish labor productivity and measured TFP fell during the boom years. Mora-Sanguinetti and Fuentes (2014) and Peeters and den Reijer (2014) also find that the Spanish economy experienced significantly weaker labour productivity growth than other OECD economies and failed to catch up with the most

\footnotetext{
${ }^{3}$ See Akin et al. (2014).
} 
advanced economies in the period 1996-2007. Nevertheless, Spain, a relatively small country in a larger monetary union (accounting for about $10 \%$ of the total size) had limited capacity to undertake policies to accommodate shocks and the interest rate was driven by the most productive countries. Within the modelling framework, we approximate this productivity differential that lead to lower interest rates in the Euro area with an idiosyncratic productivity shock that hit the monetary union except Spain.

Two other factors that may have caused the boom in the Spanish economy were loosening credit conditions, and asset bubbles. Akin et al (2011) estimate that these three factors all fuelled a sharp rise in Spanish investment and house prices, and increased the fragility of the balance sheets of Spanish households and non-financial firms. Fernandez-Villaverde et al. (2013) also find that interest rate convergence mattered for Spain, but asset bubbles and the loosening of credit constraints for households and firms had a more pronounced role. ${ }^{4}$ As a consequence, real house prices (relative to the GDP deflator) rose by $80 \%$ between 2001 and 2008. Thus, clearly a housing bubble developed in Spain, before the crisis. Moro and Nuño (2012) find that the house price differential between Spain and Germany was mainly demand driven. ${ }^{5}$ In our model, the asset bubble in Spain is approximated by a housing demand shock.

However, given its inability of cope with these problems within the monetary union setting, the Bank of Spain made use of alternative policies in order to counteract the boom, namely macroprudential policies. Spain was pioneer on the use of countercyclical buffers; it implemented a macroprudential tool called dynamic provisioning. Nevertheless, despite these regulatory constraints, Spain could not avoid a credit and housing bubble.

Macroprudential policies are particularly relevant in the context of monetary unions given that monetary policy alone cannot be used to stabilize the economy of a particular member if the economy is hit by an asymmetric shock or when there are structural differences across members. ${ }^{6}$ Therefore, they are very important for a case like the Spanish one. First, productivity shocks were hitting its partners more strongly. Second, housing demand shocks were more important in Spain, as it has previously been previously exposed. And, finally, common interest rate shocks were transmitted more strongly to Spanish households due to variable-rate mortgages and higher LTVs. ${ }^{7}$

As a result, the Bank of Spain, which is also the Spanish banking supervisory authority, implemented

\footnotetext{
${ }^{4}$ See Shirai (2014) or Diemer and Vollmer (2015) about loosening of credit constraints in Japan in recent years.

${ }^{5}$ In Spain, house prices more than doubled in the decade 1997-2007 whereas in Germany, house prices fell by more than $10 \%$ after 2003.

${ }^{6}$ See Jeanne and Korinek (2014)

${ }^{7}$ See Rubio (2011).
} 
the countercyclical dynamic provisioning tool in 2000 to fight against a sharp increase in credit risk on Spanish banks' balance sheets following a period of significant credit growth during the late 1990s. ${ }^{8}$ Dynamic provisions are now counted as a macroprudential tool, at the time they were implemented with the idea that banks should build up a buffer in good times to be used in bad times to protect its solvency. ${ }^{9}$ However, even though they contribute to mitigate the credit boom, dynamic provisions, on their own, did not suffice to cope with all the credit losses of the downturn. A macroprudential tool like this one should have been accompanied probably by other countercyclical tools, specially for the Spanish housing sector. For instance, despite the provisioning, LTVs were still very high, contributing to increasing bank risk. Using the LTV as a countercyclical tool to avoid excessive growth could have been an alternative or a complement of dynamic provisioning. The housing price is one of the indicators selected jointly with credit to estimate the financial cycle and it is almost always included in the group of leading indicators of banking crisis, so it makes sense to consider it as an indicator to change LTVs (Claessens et al., 2011). In this paper, we study the optimality of this policy to soften credit cycles by proposing a countercyclical rule for the LTV that mainly responds to house prices.

\section{Model Setup}

We consider an infinite-horizon, two-country, two-sector economy inside a monetary union. The home country (Spain) is denoted by SP and the rest of the union by EUR. Households consume, work, and demand real estate. There is a financial intermediary in each country that provides mortgages and accepts deposits from consumers. Each country produces one differentiated intermediate good, but households consume goods from both countries. For simplicity, housing is a non-traded good. We assume that labor is immobile across the countries. Firms follow a standard Calvo problem. In this economy, both final and intermediate goods are produced. Prices are sticky in the intermediate-goods sector. There is a construction sector that produces houses. Monetary policy is conducted by a single central bank that responds to a weighted average of inflation in both countries. There is a rule to the LTV which serves as a macroprudential measure. We allow for housing-market heterogeneity across the countries.

\footnotetext{
${ }^{8}$ See Saurina (2011)

${ }^{9}$ Jiménez and Saurina (2006).
} 


\subsection{The Consumer's Problem}

There are three types of consumers in each country: unconstrained consumers; constrained consumers who borrow at a variable rate; and constrained consumers who borrow at a fixed rate. The proportion of each type of borrower is fixed and exogenous. ${ }^{10}$ Consumers can be constrained or unconstrained in the sense that constrained individuals need to collateralize their debt repayments in order to borrow from the financial intermediary. Interest payments in the next period cannot exceed a proportion of the future value of the current house stock. In this way, the financial intermediary ensures that borrowers are going to be able to fulfill their debt obligations in the next period. As in Iacoviello (2005), we assume that constrained consumers are more impatient than unconstrained ones. ${ }^{11}$ There is a financial intermediary in each country. The financial intermediary in SP accepts deposits from domestic savers, and it extends both fixed- and variable-rate loans to domestic borrowers.

\subsubsection{Unconstrained Consumers (Savers)}

Unconstrained consumers in SP maximize as follows:

$$
\max E_{0} \sum_{t=0}^{\infty} \beta^{t}\left(\ln C_{t}^{u}+j \ln H_{t}^{u}-\frac{\left(L_{t}^{u}\right)^{\eta}}{\eta}\right)
$$

Here, $E_{0}$ is the expectation operator, $\beta \in(0,1)$ is the discount factor, and $C_{t}^{u}, H_{t}^{u}$, and $L_{t}^{u}$ are consumption at $t$, the stock of housing, and hours worked, respectively. ${ }^{12} j$ represents the weight of housing in the utility function. $1 /(\eta-1)$ is the aggregate labor-supply elasticity.

Consumption is a bundle of domestically and foreign-produced goods, defined as: $C_{t}^{u}=\left(C_{S P t}^{u}\right)^{n}\left(C_{E U R t}^{u}\right)^{1-n}$, where $n$ is the size of SP. Unconstrained consumers provide labor to both the consumption and construction sector, so that $L_{t}^{u}=\left[\left(L_{c t}^{u}\right)^{1-\nu}+\left(L_{h t}^{u}\right)^{1-\nu}\right]^{\frac{1}{1-\nu}}$.

The budget constraint for SP is as follows:

\footnotetext{
${ }^{10}$ As in Rubio (2011), we leave this porportion fixed an exogenous. According to the European Mortgage Federation, the type of mortgage contracts across countries responds to a large extent to institutional or cultural factors, which are out of the scope of the present model. In the short run, the proportion of each type of mortgage contract can fluctuate, but typically it does not imply a change in the fixed- or variable-rate category of the country.

${ }^{11}$ This assumption ensures that the borrowing constraint is binding in the steady state and that the economy is endogenously split into borrowers and savers.

${ }^{12}$ It is assumed that housing services are proportional to the housing stock.
} 


$$
\begin{gathered}
P_{S P t} C_{S P t}^{u}+P_{E U R t} C_{E U R t}^{u}+Q_{S P t} H_{t}^{u}+R_{S P t-1} B_{t-1}^{u}+R_{t-1} D_{t-1}+\frac{\psi}{2} D_{t}^{2} \leq Q_{S P t} H_{t-1}^{u}+ \\
W_{c t}^{u} L_{c t}^{u}+W_{h t}^{u} L_{h t}^{u}+B_{t}^{u}+D_{t}+P_{S P t} F_{t}+P_{S P t} S_{t}
\end{gathered}
$$

where $P_{S P t}$ and $P_{E U R t}$ are the prices of the goods produced in Countries SP and EUR, respectively, $Q_{t}$ is the housing price in SP, and $W_{c t}^{u}$ and $W_{h t}^{u}$ are the consumption and housing sector wages for unconstrained consumers. $B_{t}^{u}$ represents domestic bonds denominated in the common currency. $R_{S P t}$ is the nominal interest rate in SP. Positive bond holdings signify borrowing, and negative signify savings. However, as we will see, this group will choose not to borrow at all: they are the savers in this economy. $D_{t}$ are foreign-bond holdings by savers in $\mathrm{SP} .{ }^{13} R_{t}$ is the nominal rate of foreign bonds, which are denominated in euros. As is common in the literature, to ensure stationarity of net foreign assets we introduce a small quadratic cost of deviating from zero foreign borrowing, $\frac{\psi}{2} D_{t}^{2} .{ }^{14}$ Savers obtain interest on their savings. $S_{t}$ and $F_{t}$ are lump-sum profits received from the firms and the financial intermediary in $\mathrm{SP}$, respectively.

Dividing by $P_{S P t}$, we can rewrite the budget constraint in terms of goods SP:

$C_{S P t}^{u}+\frac{P_{E U R t}}{P_{S P t}} C_{E U R t}^{u}+q_{S P t} H_{t}^{u}+\frac{R_{S P t-1} b_{t-1}^{u}}{\pi_{S P t}}+\frac{R_{t-1} d_{t-1}}{P_{S P t}}+\frac{\psi}{2} d_{t}^{2} \leq q_{S P t} H_{t-1}^{u}+w_{c t}^{u} L_{c t}^{u}+w_{h t}^{u} L_{h t}^{u}+b_{t}^{u}+d_{t}+F_{t}+S_{t}$,

where $\pi_{S P t}$ denotes inflation for the goods produced in SP, defined as $P_{S P t} / P_{S P t-1}$.

Maximizing (1) subject to (3), we obtain the first-order conditions for the unconstrained group:

$$
\begin{gathered}
\frac{C_{S P t}^{u}}{C_{E U R t}^{u}}=\frac{n P_{E U R t}}{(1-n) P_{S P t}} \\
\frac{1}{C_{S P t}^{u}}=\beta E_{t}\left(\frac{R_{S P t}}{\pi_{S P t+1} C_{S P t+1}^{u}}\right), \\
\frac{1-\psi d_{t}}{C_{S P t}^{u}}=\beta E_{t}\left(\frac{R_{t}}{\pi_{S P t+1} C_{S P t+1}^{u}}\right),
\end{gathered}
$$

\footnotetext{
${ }^{13}$ Savers have access to international financial markets.

${ }^{14}$ See Iacoviello and Smets (2006) for a similar specification of the budget constraint.
} 


$$
\begin{gathered}
w_{c t}^{u}=\left(L_{t}^{u}\right)^{\eta-1}\left(L_{c t}^{u}\right)^{-\nu}\left[\left(L_{c t}^{u}\right)^{1-\nu}+\left(L_{h t}^{u}\right)^{1-\nu}\right]^{\frac{\nu}{1-\nu}} \frac{C_{S P t}^{u}}{n}, \\
w_{h t}^{u}=\left(L_{t}^{u}\right)^{\eta-1}\left(L_{h t}^{u}\right)^{-\nu}\left[\left(L_{c t}^{u}\right)^{1-\nu}+\left(L_{h t}^{u}\right)^{1-\nu}\right]^{\frac{\nu}{1-\nu}} \frac{C_{S P t}^{u}}{n}, \\
\frac{j}{H_{t}^{u}}=\frac{n}{C_{A P t}^{u}} q_{S P t}-\beta E_{t} \frac{n}{C_{S P t+1}^{u}} q_{S P t+1} .
\end{gathered}
$$

Equation (4) equates the marginal rate of substitution between goods to the relative price. Equation (5) is the Euler equation for consumption. Equation (6) is the first-order condition for net foreign assets. Equations (7) and (8)are the labor-supply conditions for both sectors. These equations are standard. Equation (9) is the Euler equation for housing and states that at the margin the benefits from consuming housing have to be equal to the costs.

Combining (5) and (6) we obtain a non-arbitrage condition between home and foreign bonds: ${ }^{15}$

$$
R_{S P t}=\frac{R_{t}}{\left(1-\psi d_{t}\right)}
$$

Since all consumption goods are traded and there are no barriers to trade, we assume in this paper that the law of one price holds:

$$
P_{S P t}=P_{S P t}^{*},
$$

where variables with a star denote foreign variables.

\subsubsection{Constrained Consumers (Borrowers)}

Constrained consumers in SP are of two types: those who borrow at a variable rate and those who do so at a fixed rate. The difference between them is the interest rate they are charged. The variablerate constrained consumer faces $R_{S P t}$, which will coincide with the rate set by the central bank. The fixed-rate borrower pays $\bar{R}_{S P t}$, derived from the financial intermediary's problem. The proportion of variable-rate consumers in Country SP is constant and exogenous and is equal to $\alpha_{S P} \in[0,1]$.

\footnotetext{
${ }^{15}$ The log-linearized version of this equation could be interpreted as the uncovered interest-rate parity.
} 
Constrained consumers are more impatient than unconstrained ones, that is $\widetilde{\beta}<\beta$. Constrained consumers face a collateral constraint: the expected debt repayment in the next period cannot exceed a proportion of the expectation of tomorrow's value of today's stock of housing:

$$
\begin{aligned}
& E_{t} \frac{R_{S P t}}{\pi_{S P t+1}} b_{t}^{c v} \leq k_{S P t} E_{t} q_{S P t+1} H_{t}^{c v}, \\
& E_{t} \frac{\bar{R}_{S P t}}{\pi_{S P t+1}} b_{t}^{c f} \leq k_{S P t} E_{t} q_{S P t+1} H_{t}^{c f},
\end{aligned}
$$

where equations (12) and (13) represent the collateral constraint for the variable- and fixed-rate borrower, respectively. $k_{S P t}$ can be interpreted as the loan-to-value ratio in SP. Notice that such models with collateral constraints, the LTV is typically considered exogenous. At the macroeconomic level, LTVs partly depend on exogenous factors such as regulation. This parameter is usually calibrated to match the average LTV in the country analyzed. However, in this model, it can vary depending on economic conditions, as a macroprudential policy variable. As we will see when we introduce the problem of the financial intermediary, $\bar{R}_{S P t}$ is an aggregate interest rate that contains information on all the past fixed-interest rates associated with past debt. Each period, this aggregate interest rate is updated with a new interest rate linked to the new amount of debt originating in that period.

Without loss of generality, we present the problem for the variable-rate borrower since that for the fixed rate is symmetrical. Variable-rate borrowers maximize their lifetime utility function:

$$
\max E_{0} \sum_{t=0}^{\infty} \widetilde{\beta}^{t}\left(\ln C_{t}^{c v}+j \ln H_{t}^{c v}-\frac{\left(L_{t}^{c v}\right)^{\eta}}{\eta}\right)
$$

where $C_{t}^{c v}=\left(C_{S P t}^{c v}\right)^{n}\left(C_{E U R t}^{c v}\right)^{1-n}, L_{t}^{c v}=\left[\left(L_{c t}^{c v}\right)^{1-\nu}+\left(L_{h t}^{c v}\right)^{1-\nu}\right]^{\frac{1}{1-\nu}}$, subject to the budget constraint (in terms of good A):

$$
C_{S P t}^{c v}+\frac{P_{E U R t}}{P_{S P t}} C_{E U R t}^{c v}+q_{S P t} H_{t}^{c v}+\frac{R_{S P t-1} b_{t-1}^{c v}}{\pi_{S P t}} \leq q_{S P t} H_{t-1}^{c v}+w_{c t}^{c v} L_{c t}^{c v}+w_{h t}^{c v} L_{t}^{c v}+b_{h t}^{c v}
$$

and subject to the collateral constraint (12). Notice that variable-rate borrowers repay all debt every period and acquire new debt at the current new interest rate. This assumption implies that the interest rate on variable-rate mortgages is revised every period for the whole stock of debt and changed according 
to the policy rate. ${ }^{16}$ To make the problem for fixed-rate borrowers symmetrical and analogous to existing models with borrowing constraints, we assume the same debt-repayment structure for this type of borrower. Obviously, fixed-rate contracts are not revised every period. However, to make the model more realistic, but still tractable, the fixed-interest rate will be such that a revised fixed rate will be applied only on new debt, keeping constant the interest rate applied to existing debt. In this way, we reconcile the structure of the model with the fact that fixed-rate contracts are long term. ${ }^{17}$

The first-order conditions for these consumers are as follows:

$$
\begin{gathered}
\frac{C_{S P t}^{c v}}{C_{E U R t}^{c v}}=\frac{n P_{E U R t}}{(1-n) P_{S P t}} \\
\frac{n}{C_{S P t}^{c v}}=\widetilde{\beta} E_{t}\left(\frac{n R_{S P t}}{\pi_{S P t+1} C_{S P t+1}^{c v}}\right)+\lambda_{t}^{c v} R_{S P t}, \\
w_{c t}^{c v}=\left(L_{t}^{c v}\right)^{\eta-1}\left(L_{c t}^{c v}\right)^{-\nu}\left[\left(L_{c t}^{c v}\right)^{1-\nu}+\left(L_{h t}^{c v}\right)^{1-\nu}\right]^{\frac{\nu}{1-\nu}} \frac{C_{S P t}^{c v}}{n}, \\
w_{h t}^{c v}=\left(L_{t}^{c v}\right)^{\eta-1}\left(L_{h t}^{c v}\right)^{-\nu}\left[\left(L_{c t}^{c v}\right)^{1-\nu}+\left(L_{h t}^{c v}\right)^{1-\nu}\right]^{\frac{\nu}{1-\nu}} \frac{C_{S P t}^{c v}}{n}, \\
\frac{j}{H_{t}^{c v}}=\frac{n}{C_{S P t}^{c v}} q_{S P t}-\widetilde{\beta} E_{t} \frac{n}{C_{S P t+1}^{c v}} q_{S P t+1}-\lambda_{t}^{c v} k_{S P t} E_{t} q_{S P t+1} \pi_{S P t+1} .
\end{gathered}
$$

These first-order conditions differ from those of unconstrained individuals. In the case of constrained consumers, the Lagrange multiplier on the borrowing constraint $\left(\lambda_{t}^{c v}\right)$ appears in equations (17) and (20). As in Iacoviello (2005), the borrowing constraint is always binding, so that constrained individuals borrow the maximum amount they are allowed, and their saving is zero. ${ }^{18}$

The problem for consumers is analogous in EUR.

\footnotetext{
${ }^{16}$ This assumption is consistent with reality, in which variable-interest rates are revised very frequently and changed according to an interest-rate index tied to the interest rate set by the central bank.

${ }^{17}$ Another option would be to have an overlapping generation model in which we are able to keep track of the debt issued each period. However, the model would become more complex and less comparable with the standard collateral constraint DSGE models, such as that of Iacoviello (2005).

${ }^{18}$ From the Euler equations for consumption of the unconstrained consumers, we know that $R_{S P}=1 / \beta$, where variables without a time subscript denote steady-state variables. If we combine this result with the Euler equation for consumption for the constrained individual, we have $\lambda^{c v}=n(\beta-\widetilde{\beta}) / C_{S P}^{c v}>0$. Given that $\beta>\widetilde{\beta}$, the borrowing constraint holds with equality in steady state. Since the model is log-linearized around the steady state and low uncertainty is assumed, this result can be generalized to off-steady-state dynamics.
} 


\subsection{The Financial Intermediary}

We assume a competitive framework, and thus the intermediary takes the variable interest rate as given. ${ }^{19}$ The profits of the financial intermediary are defined as: ${ }^{20}$

$$
F_{t}=\alpha_{S P} R_{S P t-1} b_{t-1}^{c v}+\left(1-\alpha_{S P}\right) \bar{R}_{S P t-1} b_{t-1}^{c f}-R_{S P t-1} b_{t-1}^{u},
$$

where $F_{t}$ are the profits of the financial intermediary. $R_{S P t}$ and $\bar{R}_{S P t}$ are the variable and the fixed rate, respectively.

In equilibrium, aggregate borrowing and saving must be equal, that is,

$$
\alpha_{S P} b_{t}^{c v}+\left(1-\alpha_{S P}\right) b_{t}^{c f}=b_{t}^{u}
$$

Substituting (22) into (21), we obtain,

$$
F_{t}=\left(1-\alpha_{S P}\right) b_{t-1}^{c f}\left(\bar{R}_{S P t-1}-R_{S P t-1}\right)
$$

For the two types of mortgage to be offered, the fixed-interest rate has to be such that the intermediary is indifferent between lending at a variable or fixed rate. Hence, the expected discounted profits that the intermediary obtains by lending new debt in a given period at a fixed-interest rate must be equal to the expected discounted profits the intermediary would obtain by lending it at a variable rate:

$$
E_{\tau} \sum_{i=\tau+1}^{\infty} \beta^{i-\tau} \Lambda_{\tau, i}{\overline{R_{S P}}}^{O P T}=E_{\tau} \sum_{i=\tau+1}^{\infty} \beta^{i-\tau} \Lambda_{\tau, i} R_{S P t-1}
$$

where $\Lambda_{t, i}=\frac{C_{S P t}^{u}}{C_{S P t+i}^{u}}$ is the unconstrained-consumer relevant discount factor. Since the financial intermediary is owned by the savers, their stochastic discount factor is applied to the financial intermediary's problem. Notice that, as stated before, variable-rate debt is in one period, but the portion of new debt acquired at a fixed rate is associated with a long-term contract. Since the agent is infinitely lived, we assume here that the maturity of fixed-rate mortgages is also infinity.

We can obtain the equilibrium value of the fixed rate in period $\tau$ from expression (24):

\footnotetext{
${ }^{19}$ See Andrés and Arce (2008) for a housing model with collateral constraints in which banks are imperfectly competitive and are able to set optimal lending rates.

${ }^{20}$ The superscript $c v$ signifies "constrained variable," $c f$ "constrained fixed".
} 


$$
\bar{R}_{S P \tau}^{O P T}=\frac{E_{\tau} \sum_{i=\tau+1}^{\infty} \beta^{i-\tau} \Lambda_{\tau, i} R_{S P t-1}}{E_{\tau} \sum_{i=\tau+1}^{\infty} \beta^{i-\tau} \Lambda_{\tau, i}} .
$$

Equation (25) states that for every new debt issued at date $\tau$, there is a different fixed-interest rate that has to be equal to a discounted average of future variable-interest rates. Notice that this is not a condition on the stock of debt, but on the new amount obtained in a given period. New debt at a given point in time is associated with a different fixed-interest rate. Both the fixed-interest rate in period $\tau$ and the new amount of debt in period $\tau$ are fixed for all future periods. Nevertheless, the fixed-interest rate varies with the date the debt was issued, so that in every period there is a new fixed-interest rate associated with new debt in this period. If we consider fixed-rate loans to be long term, the financial intermediary obtains interest payments every period from the whole stock of debt, not only from the new ones. Hence, we can define an aggregate fixed-interest rate as the one the financial intermediary effectively charges every period for the whole stock of mortgages. This aggregate fixed-interest rate is composed of all past fixed-interest rates and past debt, together with the current-period equilibrium fixed-interest rate and new amount of debt. Therefore, the effective fixed-interest rate that the financial intermediary charges for the stock of fixed-rate debt every period is as follows:

$$
\bar{R}_{S P t}=\left\{\begin{array}{c}
\frac{\bar{R}_{S P t-1} b_{t-1}^{c f}+\bar{R}_{S P t}^{O P T}\left(b_{t}^{c f}-b_{t-1}^{c f}\right)}{b_{t}^{c f}} \text { if } b_{t}^{c f}>b_{t-1}^{c f} \\
\bar{R}_{S P t-1} \text { if } b_{t}^{c f} \leq b_{t-1}^{c f}
\end{array}\right\} .
$$

Equation (26) states that the fixed-interest rate that the financial intermediary charges today is an average of what it charged the previous period for the previous stock of mortgages and what it charges in the current period for the new amount. If there is no new debt, the fixed-interest rate will be equal to that of the previous period. Then, in the same way that variable rates are revised every period, fixed-rates are revised by including the new optimal fixed-interest rate for the new debt originating in this period. Importantly, this assumption is not crucial for results. Both $\bar{R}_{S P \tau}^{O P T}$ and $\bar{R}_{S P t}$ are practically unaffected by interest rate shocks. ${ }^{21}$ This assumption is a way to make the model compatible with the fact that fixed-rate loans are not one-period assets but longer-term ones.

As noted above, any profits from financial intermediation are rebated to the unconstrained consumers every period. Even if the financial intermediary is competitive and does not make profits in the absence

\footnotetext{
${ }^{21}$ In log-linearized terms, the new fixed interest rate is always equal to the past fixed interest rate, therefore, equation (26) does not introduce a kink.
} 
of shocks; should a shock occur, the fact that only the variable-interest rate is directly affected can generate non-zero profits. ${ }^{22}$

The financial intermediary problem for EUR is symmetrical.

\subsection{Firms}

\subsubsection{Final-Consumption Goods Producers}

In SP, there is a continuum of final-goods producers that aggregate intermediate goods according to the production function:

$$
Y_{S P t}^{k}=\left[\int_{0}^{1} Y_{S P t}^{k}(z)^{\frac{\varepsilon-1}{\varepsilon}} d z\right]^{\frac{\varepsilon}{\varepsilon-1}}
$$

where $\varepsilon>1$ is the elasticity of substitution among intermediate goods.

The total demand of intermediate-good $z$ is given by $Y_{S P t}(z)=\left(\frac{P_{S P}(z)}{P_{S P t}}\right)^{-\varepsilon} Y_{S P t}$, and the price index is $P_{S P t}=\left[\int_{0}^{1} P_{S P t}(z)^{1-\varepsilon} d z\right]^{\frac{1}{\varepsilon-1}}$.

\subsubsection{Intermediate-Goods and House Producers}

The intermediate-goods consumption market is monopolistically competitive. Following Iacoviello (2005), intermediate goods are produced according to the following production function:

$$
Y_{S P t}(z)=\xi_{t}\left(L_{c t}^{u}(z)\right)^{\gamma}\left(L_{c t}^{c}(z)\right)^{(1-\gamma)},
$$

where $\xi_{t}$ represents technology. We assume that $\log \xi_{t}=\rho_{\xi} \log \xi_{t-1}+u_{\xi t}$, where $\rho_{\xi}$ is the autoregressive coefficient and $u_{\xi t}$ is a normally distributed shock to technology. $\gamma \in[0,1]$ measures the relative size of each group in terms of labor. $L_{t}^{c}$ is labor supplied by constrained consumers, defined as $\alpha_{S P} L_{t}^{c v}+$ $\left(1-\alpha_{S P}\right) L_{t}^{c f}$.

Symmetry across firms allows avoiding index $z$ and re-writing equation (28) as:

$$
Y_{S P t}=\xi_{t}\left(L_{c t}^{u}\right)^{\gamma}\left(L_{c t}^{c}\right)^{(1-\gamma)}
$$

The production function for housing investment is as follows:

\footnotetext{
${ }^{22}$ This modelling of the fixed interest rate follows Rubio (2011) and Rubio (2014).
} 


$$
I_{S P t}=\xi_{t}\left(L_{h t}^{u}\right)^{\gamma}\left(L_{h t}^{c}\right)^{(1-\gamma)}
$$

Producers maximize profits:

$$
\max _{L_{c t}, L_{h t}} \frac{Y_{S P t}}{X_{t}}+q_{t} I_{S P t}-w_{c t}^{u} L_{c t}^{u}-w_{h t}^{u} L_{h t}^{u}-w_{c t}^{c v} L_{c t}^{c v}-w_{h t}^{c v} L_{t}^{c v}-w_{c t}^{c f} L_{c t}^{c f}-w_{h t}^{c f} L_{t}^{c f}
$$

The first-order conditions for labor demand are the following:

$$
\begin{gathered}
w_{c t}^{u}=\frac{1}{X_{t}} \gamma \frac{Y_{S P t}}{L_{c t}^{u}}, \\
w_{c t}^{c v}=w_{c t}^{c f}=\frac{1}{X_{t}}(1-\gamma) \frac{Y_{S P t}}{L_{c t}^{c}}, \\
w_{h t}^{u}=\gamma \frac{q_{t} I_{S P t}}{L_{h t}^{u}}, \\
w_{h t}^{c v}=w_{h t}^{c f}=(1-\gamma) \frac{q_{t} I_{S P t}}{L_{h t}^{c}},
\end{gathered}
$$

where $X_{t}$ is the markup, or the inverse of marginal cost.

The price-setting problem for the intermediate-goods producers is a standard Calvo-Yun case. An intermediate-goods producer sells goods at price $P_{S P t}(z)$, and $1-\theta$ is the probability of being able to change the sale price in every period. The optimal reset price $P_{S P t}^{O P T}(z)$ solves the following:

$$
\sum_{k=0}^{\infty}(\theta \beta)^{k} E_{t}\left\{\Lambda_{t, k}\left[\frac{P_{S P t}^{O P T}(z)}{P_{S P t+k}}-\frac{\varepsilon /(\varepsilon-1)}{X_{t+k}}\right] Y_{S P t+k}^{O P T}(z)\right\}=0 .
$$

The aggregate price level is given as follows:

$$
P_{S P t}=\left[\theta P_{S P t-1}^{1-\varepsilon}+(1-\theta)\left(P_{S P t}^{O P T}\right)^{1-\varepsilon}\right]^{1 /(1-\varepsilon)} .
$$

Using (36) and (37) and log-linearizing, we can obtain the standard forward-looking Phillips curve. ${ }^{23}$ The firm problem is similar in EUR.

\footnotetext{
${ }^{23}$ This Phillips curve is consistent with other two-country models with financial accelerator. See for instance Gilchrist et al (2002) or Iacoviello and Smets (2006).
} 


\subsection{Aggregate Variables and Market Clearing}

Given $\alpha_{S P}$, the fraction of variable-rate borrowers in SP, we can define aggregates across constrained consumers as the sum of variable-rate and fixed-rate aggregates, so that $C_{t}^{c} \equiv \alpha_{S P} C_{t}^{c v}+\left(1-\alpha_{S P}\right) C_{t}^{c f}$, $H_{t}^{c} \equiv \alpha_{S P} H_{t}^{c v}+\left(1-\alpha_{S P}\right) H_{t}^{c f}$ and $b_{t}^{c} \equiv \alpha_{S P} b_{t}^{c v}+\left(1-\alpha_{S P}\right) b_{t}^{c f}$.

Therefore, economy-wide aggregates in Country SP are $C_{t} \equiv C_{t}^{u}+C_{t}^{c}, L_{t} \equiv L_{t}^{u}+L_{t}^{c}$. Domestic housing market clearing requires $I_{S P t} \equiv\left(H_{t}^{u}-H_{t-1}^{u}\right)+\left(H_{t}^{c}-H_{t-1}^{c}\right)$.

The market clearing condition for the final good in Country SP is $n Y_{S P t}=n C_{S P t}+(1-n) C_{S P t}^{*}+$ $n \frac{\psi}{2} d_{t}^{2}$. Domestic financial markets clear: $b_{t}^{c}=b_{t}^{u}$. The world bond market clearing condition is $n d_{t}+$ $(1-n) \frac{P_{E U R t}}{P_{S P t}} d_{t}^{*}=0$, where $d_{t}$ denotes the foreign bonds in real terms. The net foreign asset position follows $d_{t}=\frac{R_{t-1}}{\left(1-\psi d_{t}\right) \pi_{S P t}} d_{t-1}+Y_{S P t}-C_{S P t}-\frac{P_{E U R t}}{P_{S P t}} C_{E U R t}$. Everything is similar in EUR.

\subsection{Monetary Policy}

The model is closed with a Taylor rule, with interest-rate smoothing for interest-rate setting by a single central bank, ${ }^{24}$

$$
R_{t}=\left(R_{t-1}\right)^{\rho}\left(\left[\left(\pi_{S P t}\right)^{n}\left(\pi_{E U R t}\right)^{(1-n)}\right]^{\left(1+\phi_{\pi}\right)} R\right)^{1-\rho} \varepsilon_{R, t}
$$

$0 \leq \rho \leq 1$ is the parameter associated with interest-rate inertia. $\left(1+\phi_{\pi}\right)$ measures the sensitivity of interest rates to current inflation. $\varepsilon_{R, t}$ is a white noise shock process with zero mean and variance $\sigma_{\varepsilon}^{2}$. This rule is consistent with the primary objective of the ECB being price stability.

\section{Dynamics}

In this section, we simulate the model to illustrate the economic situation that preceded the crisis in Spain. We show, within the model, the effects and the mechanisms that follow after a negative interestrate shock, a positive productivity shock in the Euro area that leads to a reduction in interest rates, and a housing demand shock in Spain. We consider that these are the three economic events that led to a housing and credit boom in Spain. We study these shocks one by one to disentangle the specific effects that each of them had on the pre-crisis Spanish economy. In particular, we study the effects on GDP, as

\footnotetext{
${ }^{24}$ This type of rule is also used in other monetary-union models. See Iacoviello and Smets (2006) or Aspachs and Rabanal (2008). Furthermore, as shown in Iacoviello (2005) and Rubio and Carrasco-Gallego (2014), a rule that only responds to inflation enhances the financial accelerator.
} 
defined by internal consumption plus exports; consumption, defined as internal demand, that is, internal consumption plus imports; house prices; borrowing; the Euro area interest rate; and CPI inflation.

\subsection{Parameter Values}

Parameters are calibrated to reflect the economy of Spain and the rest of the Euro area. Some of the parameters are standard and are common for both economies and some others will be specifically calibrated for each country. Tables A1 and A2 in the Appendix present a summary of the parameter values.

Discount factors are set to be common in both economies, following the standard values in the literature. The discount factor for savers, $\beta$, is set to 0.99 so that the annual interest rate is $4 \%$ in steady state. The discount factor for borrowers, $\widetilde{\beta}$, is set to $0.98 .^{25}$ The steady-state weight of housing in the utility function, $j$, is set to 0.12 and 0.143 , in the Euro area and Spain, respectively. This parameter pins down the ratio of housing wealth to GDP. ${ }^{26}$ We set $\eta=2$, implying a value of the labor supply elasticity of $1 .{ }^{27}$ Following Horvath (2000) and Iacoviello and Neri (2010), we set the inverse elasticity of substitution across hours in the two sectors to one.For the loan-to-value ratio we consider a steady-state value of 0.67 and 0.80 , for the Euro area and Spain, respectively, taking the average LTV ratio observed in the data. ${ }^{28}$ The labor-income share of unconstrained consumers, $\gamma$, is set to $0.7{ }^{29}$ We pick a value of 6 for $\varepsilon$, the elasticity of substitution among intermediate goods. This value implies a steady-state markup of 1.2. The probability of not changing prices, $\theta$, is set to 0.75 , implying that prices change every four quarters on average. For the Taylor Rule parameters, we use $\rho=0.8, \phi_{\pi}=0.5$. The first value reflects a realistic degree of interest-rate smoothing. ${ }^{30} \phi_{\pi}$ is consistent with the original parameters proposed by Taylor in 1993. We consider $\alpha$, the proportion of variable-rate mortgages, to be 0.35 and 0.75 , in the Euro area and Spain, respectively. The size of Spain is considered to be $10 \%{ }^{31} \mathrm{~A}$ technology shock is a $1 \%$ positive technology with 0.9 persistence. ${ }^{32}$ Tables A3 and A4 in the Appendix present some of the

\footnotetext{
${ }^{25}$ Lawrance (1991) estimated discount factors for poor consumers at between 0.95 and 0.98 at quarterly frequency.

${ }^{26}$ Following Aspachs and Rabanal (2008), I use 1.40, value that reflects the ratio of housing wealth to GDP across most industrialized countries as a proxy for the Euro area. For Spain, this parameter is calibrated in Ortega et al. (2011).

${ }^{27}$ Microeconomic estimates usually suggest values in the range of 0 and 0.5 (for males). Domeij and Flodén (2006) showed that in the presence of borrowing constraints this estimate could have a downward bias of $50 \%$.

${ }^{28}$ We use 0.675 for the loan-to-value ratio,consistently with data from the European Mortgage Federation (Spain Factsheet 2009)

${ }^{29}$ This value is in the range of the estimates of Iacoviello (2005) and Iacoviello and Neri (2010) for the US, and Campbell and Mankiw (1991) for the US, Canada, France, and Sweden. Therefore, I take it as valid for most of the countries of the Euro area.

${ }^{30}$ See McCallum (2001).

${ }^{31}$ We follow Andres et al. (2010).

${ }^{32}$ This high persistence value for technology shocks is consistent with what is commonly reported in the literature. Smets
} 

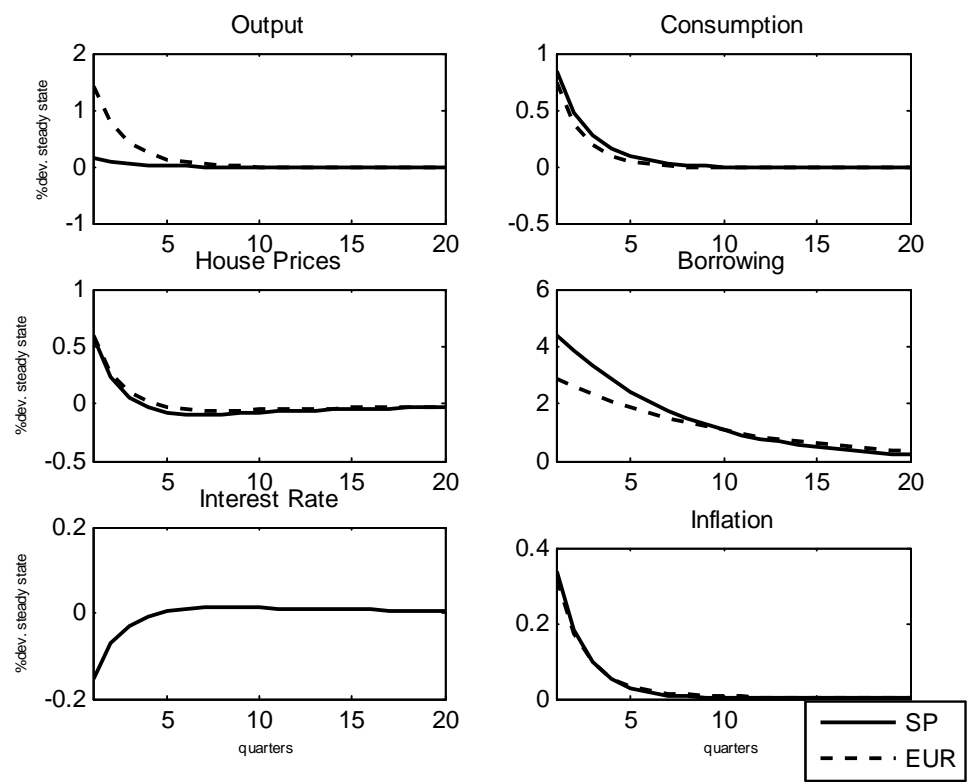

Figure 1: Impulse Responses to an Interest rate shock in the Euro area. Spain versus rest of the Euro zone.

data used for calibration. ${ }^{33}$

\subsection{Impulse Responses}

\subsubsection{Impulse responses to a negative interest-rate shock}

The ECB and other central banks, previous to the crisis, implemented unprecedented loose monetary policies. Interest rates were at a very low levels and this caused credit to grow. In this section, we proxy this ECB policy as a negative interest-rate shock. In Figure 1, we see that loose credit conditions in the Euro area lead to an increase in borrowing, especially in Spain. The reason why this credit growth was stronger in Spain is mainly because the structure of mortgage contracts in this economy, variable rates, and the fact that LTV were also higher than the European average. These two characteristics of the Spanish economy made Spanish households more sensitive to changes in interest rates, due to a stronger pass-through of the policy rate and a stronger financial accelerator effects. Nevertheless, these facts alone could not explain the differences in house price growths that we observed between Spain and the core countries in the Euro area. The negative interest-rate shock causes a common demand shock in those two areas but it exacerbates the credit boom in Spain without translating to a house price and Wouters (2002) estimated a value of 0.822 for this parameter in Europe; Iacoviello and Neri (2010) estimated it as 0.93 for the US.

${ }^{33}$ Results are robust to the country size and the persistence of the technology shock. 

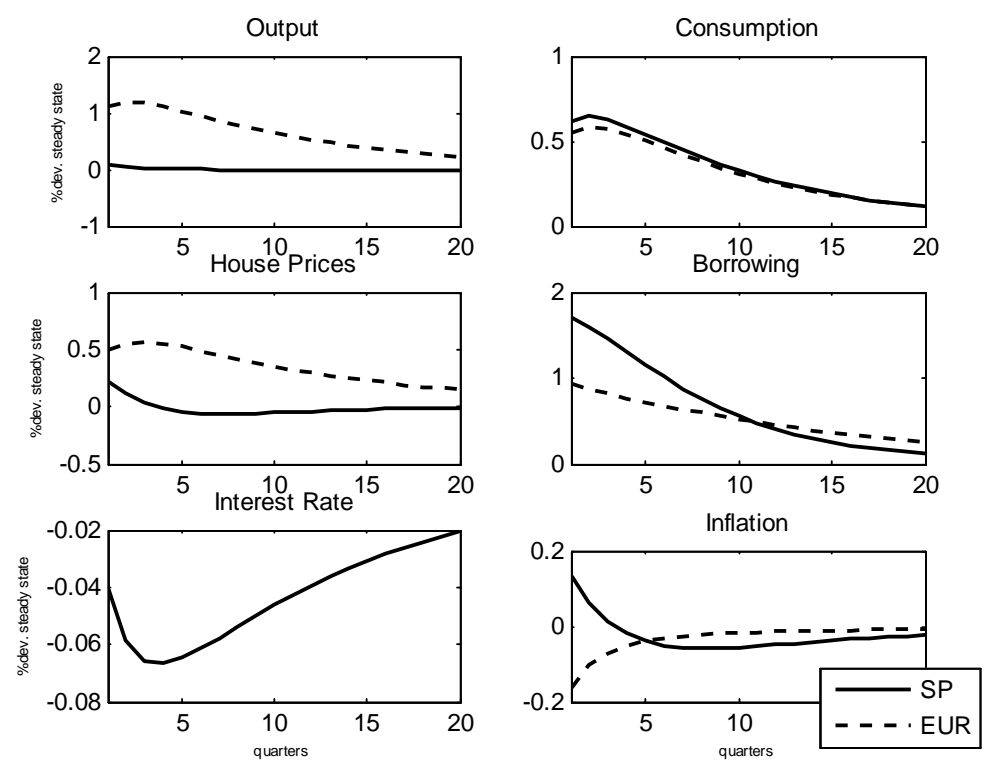

Figure 2: Impulse Responses to a Productivity Shock in the rest of the Euro area. Spain versus rest of Euro zone.

boom which is stronger than in the case of its partners. In terms of consumption, demand increases in both countries due to the lower interest rates and slightly more in Spain because Spanish households are borrowing by more than in the rest of the Euro area. GDP is increasing by more in the Euro area because this is the country that is absorbing the increase in demand and producing more for internal and external demand.

\subsubsection{Impulse Responses to a Technology Shock in EUR}

Figure 2 illustrates another factor that contributed to the credit boom in Spain previous to the crisis. Productivity differentials between Spain and its European partners increased after the launch of the Euro. The rest of the Euro area (i.e. Germany and the core countries) was having a productivity shock that increased output and decreased inflation. Lower inflation rates in the core countries, which have a higher weight in the Taylor rule, made the systematic component of the policy rule respond lowering interest rates. The decrease in the interest rate, in the context of the monetary union, was common to Spain as well. Spain was not benefitting from a productivity shock but it was transmitted to this country in the form of lower interest rates, loosening credit conditions. Thus, a supply shock in the Euro area became a demand shock in Spain, due to lower interest rates. Therefore, consumption in Spain also increased, as in the rest of the Euro area but at the expense of higher inflation and a credit boom that was stronger than in the core countries. However, as in the case of the previous shock, loose credit 

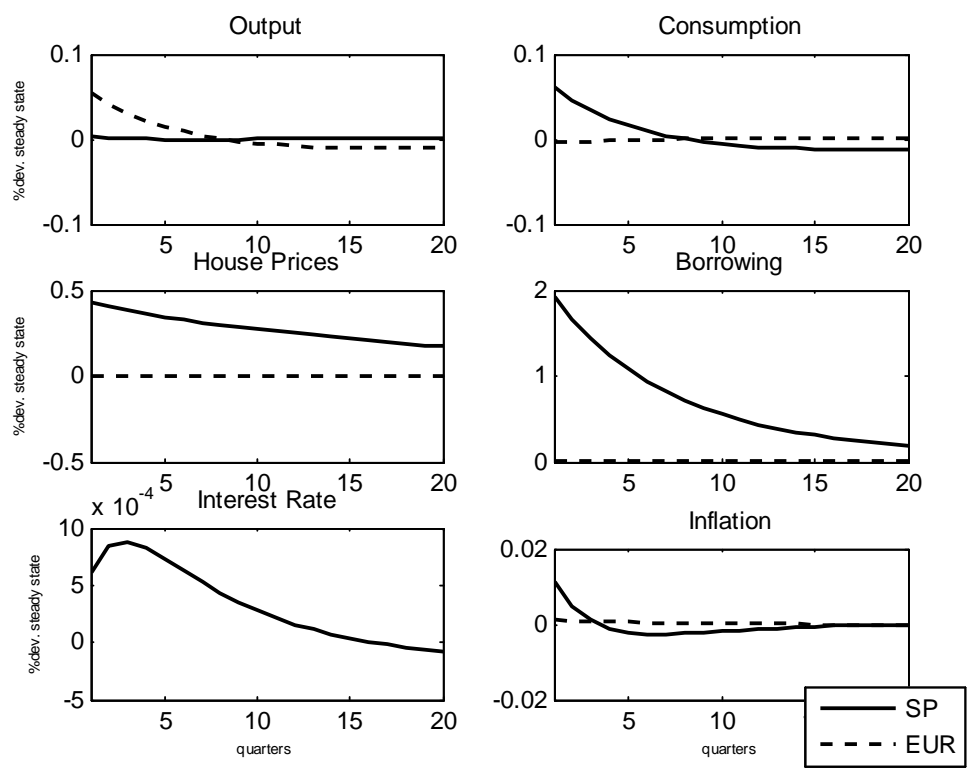

Figure 3: Impulse Responses to a Housing Demand Shock in Spain. Spain versus rest of the Euro zone. conditions can explain a stronger credit boom in Spain but not a higher house price growth than in the rest of the Euro area. Also as in the previous case, the Euro area absorbed the increase in demand for consumer goods that happened in both countries.

\subsubsection{Impulse Responses to a Housing Demand Shock in SP}

In order to explain the higher house price growth in Spain, we assume that Spain suffered a housing demand shock that was translated to higher house prices. Figure 3 illustrates the effect of this shock. We see that an increase in the preference for houses produces an increase in housing prices in Spain. Since the value of the collateral is higher in Spain, borrowing increases, creating a credit boom. Even if the three shocks analyzed create a credit boom that is higher in Spain, this is the shock that can explain the higher increase in house prices in this country, as compared to its European partners.

\section{Macroprudential Policy}

As an approximation for a realistic macroprudential policy, we consider a Taylor-type rule for the loanto-value ratio. In standard models, the LTV ratio is a fixed parameter which is not affected by economic conditions. However, we can think of regulations of LTV ratios as a way to moderate credit booms. When the LTV ratio is high, the collateral constraint is less tight. And, since the constraint is binding, borrowers will borrow as much as they are allowed to. Lowering the LTV tightens the constraint and 
therefore restricts the loans that borrowers can obtain. Recent research on macroprudential policies has proposed Taylor-type rules for the LTV ratio so that it reacts inversely to variables such that the growth rates of GDP, credit, the credit-to-GDP ratio or house prices. These rules can be a simple illustration of how a macroprudential policy could work in practice. Here, we assume that there exists a macroprudential Taylor-type rule for the LTV ratio in Spain, so that it responds to output and house prices. ${ }^{34}$ The first variable would correspond to the objective of the macroprudential regulator to moderate booms in the economy that could lead to an excessive credit growth. As for the house prices, given collateral constraints, they are the key causal variable for the dynamics of loans to households, and it appears to correspond to the actual behavior of policymakers. ${ }^{35}$ We consider a decentralized macroprudential policy in which each country can implement its own rule:

$$
k_{S P t}=k_{S S \_S P}\left(\frac{q_{S P t}}{q_{S P}}\right)^{-\phi_{q}^{k}}\left(\frac{Y_{S P t}}{Y_{S P}}\right)^{-\phi_{Y}^{k}},
$$

where $k_{S S \_S P}, q_{S P}$ and $Y_{S P}$ are the steady-state values for the loan-to-value ratio, house prices and output in Spain. $\phi_{q}^{k} \geq 0, \phi_{Y}^{k} \geq 0$ measure the response of the loan-to-value to deviations of housing and output from their steady state. This kind of rule would be countercyclical, delivering a lower LTV ratio in booms, therefore restricting the credit in the economy.

In order to find the optimal macroprudential policy, we consider the values of the rule parameters that maximize welfare for Spain. The following subsection describes the welfare measure.

\subsection{Welfare Measure}

In order to provide a measure for welfare, we numerically evaluate how cross-country asymmetries affect welfare for a given policy rule and for technology shocks. As discussed in Benigno and Woodford (2008), the two approaches that have recently been used for welfare analysis in DSGE models include either characterizing the optimal Ramsey policy, or solving the model using a second-order approximation to the structural equations for given policy and then evaluating welfare using this solution. As in Mendicino and Pescatori (2007), we take this latter approach to be able to evaluate the welfare of the three types of agents separately. ${ }^{36}$ The individual welfare for savers and borrowers in Country SP is

\footnotetext{
${ }^{34}$ I have also experimented with rules that react directly to credit growth and results for the dynamics of the model are similar.

${ }^{35}$ See Angelini et al. (2012) for further discussion.

${ }^{36}$ We used the software Dynare to obtain a solution for the equilibrium implied by a given policy by solving a second-order approximation to the constraints, then evaluating welfare under the policy using this approximate solution, as in SchmittGrohe and Uribe (2004). See Monacelli (2006) for an example of the Ramsey approach in a model with heterogeneous
} 
defined, respectively, as follows:

$$
\begin{aligned}
V_{u, t} & \equiv E_{t} \sum_{m=0}^{\infty} \beta^{m}\left(\ln C_{t+m}^{u}+j \ln H_{t+m}^{u}-\frac{\left(L_{t+m}^{u}\right)^{\eta}}{\eta}\right), \\
V_{c v, t} & \equiv E_{t} \sum_{m=0}^{\infty} \widetilde{\beta}^{m}\left(\ln C_{t+m}^{c v}+j \ln H_{t+m}^{c v}-\frac{\left(L_{t+m}^{c v}\right)^{\eta}}{\eta}\right),
\end{aligned}
$$

Following Mendicino and Pescatori (2007), we define social welfare in SP as a weighted sum of the individual welfare for the different types of households:

$$
V_{t}=(1-\beta) V_{u, t}+(1-\widetilde{\beta})\left[\alpha_{A} V_{c v, t}+\left(1-\alpha_{A}\right) V_{c f, t}\right]
$$

Borrowers and savers' welfare are weighted by $(1-\widetilde{\beta})$ and $(1-\beta)$, respectively, so that the two groups receive the same level of utility from a constant consumption stream. Everything is symmetrical for EUR.

Total welfare is defined as a weighted sum of the welfare in the two countries:

$$
W_{t}=n V_{t}+(1-n) V_{t}^{*}
$$

In order to make the results more intuitive, we present welfare changes in terms of consumption equivalents. We use as a benchmark the welfare evaluated when the macroprudential policy is not active and compare it with the welfare obtained when such policy is implemented. ${ }^{37}$

\subsection{Optimal Macroprudential Policy}

Table 1 presents the optimized parameters of the macroprudential rule. We take monetary policy as given and search over the parameters that maximize welfare in Spain.

\begin{tabular}{c|c|c}
\hline \hline \multicolumn{2}{c}{ Table1: Optimal Macroprudential Policy } \\
\hline \hline Optimal Parameters & $\phi_{q}^{k}=0.62$ & $\phi_{Y}^{k}=0.03$ \\
\hline Welfare gain & \multicolumn{2}{|c}{2.093} \\
\hline \hline
\end{tabular}

In Table 1, we find the optimal parameters for the LTV rule described in equation 39. The first parameter corresponds to the reaction of the LTV to housing prices, while the second one is the output consumers.

${ }^{37}$ We follow Ascari and Ropele (2009). 

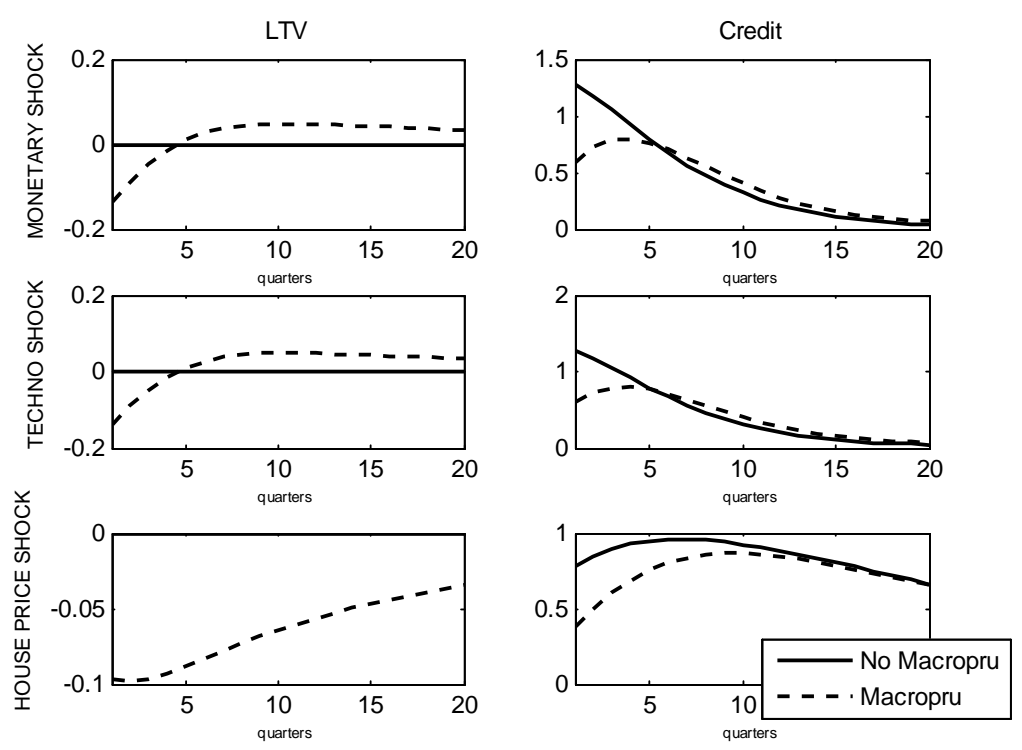

Figure 4: Impulse Responses to Monetary, Technology and Housing Demand Shocks. LTV and Credit in Spain. Macroprudential versus no macroprudential policy.

reaction parameter. The larger the value of this parameter, the more the LTV reacts to changes in housing prices or output, respectively. We see that the optimal rule for Spain is one in which the LTV mainly responds to house prices, as the main indicator of credit excesses. Therefore, it means that whenever house prices increase, the macroprudential regulator should see this as an indication of a housing market excess and cut the LTV accordingly.

Furthermore, in the table, we present the gains in terms of welfare that implementing this optimal rule represents. Putting this rule in place gives a welfare gain to Spain (in consumption equivalents) of more than $2 \%$, with respect to a situation in which there are no macroprudential policies. ${ }^{38}$ Welfare gains are coming from the fact that borrowers are better off with macroprudential policies. Since, in this model, the collateral constraint is always binding, borrowers are not able to smooth consumption as savers do. Therefore, a policy that enhances financial stability brings them a more stable scenario with a more stable consumption path.

Figure 4 displays impulse responses for Spain with the optimized parameters found in Table. Impulse responses are calculated for the three previous shocks; a negative interest-rate shock, a productivity shock in the Euro area and a housing demand shock in Spain. We compare the case in which macroprudential policies are not in place with the case of the optimal macroprudential rule. We see that if the optimal

\footnotetext{
${ }^{38}$ Notice that although this welfare gain may seem rather large, we are not optimizing over monetary policy and therefore the starting point is a non-optimal one. Thus, when optimizing over macroprudential policies gains are large.
} 
macroprudential rule is implemented, the credit boom is softened due to a decrease in the LTV. In the three cases, the shocks are generating a boom in the housing market. However, with this macroprudential policy, the credit boom can be mitigated, which is the objective of the macroprudential regulator.

\section{Concluding Remarks}

In this paper, we build a two-country DSGE model, with housing, and collateral constraints in order to illustrate the housing boom that preceded the crisis in Spain, and the effects of macroprudential policies that were implemented by the Bank of Spain. Within this setting, countries take part of a monetary union in which monetary policy is set by a single central bank. For the case of macroprudential policies, there is a macroprudential LTV rule in Spain that responds to deviations of house prices and output with respect to their steady states.

This paper is novel in the sense that it studies macroprudential policies in Spain in a DSGE framework. Furthermore, within this setting, it provides answers in terms of optimality and welfare gains of an LTV rule for macroprudential purposes.

The model is appropriately calibrated to reflect the Spanish economy and the rest of the Euro area. In particular, it accounts for the higher LTVs and housing wealth in Spain, the small weight of the country within the Euro area, as well as for the fact that the majority of mortgages in Spain are variable rate.

In this framework, we illustrate that looser credit conditions from Spain, coming from monetary policy shocks or lower interest rates responding to increases in productivity in the Euro area, may have contributed to the credit boom that the Spanish economy experienced before the crisis. This, together with a housing demand shock could explain the stronger increase in credit and house prices in Spain, with respect to its European partners.

When we assess the optimal macroprudential policies that could have been implemented by the central bank in order to avoid the credit boom in Spain, we find that a countercyclical LTV rule that mainly responds to increases in house prices, could have mitigated the credit boom. These results could be extended to other economies with similar problems in their housing markets. Moreover, for further research, it would be also interesting to explore the capital requirement ratio as an additional macroprudential tool. 


\section{Appendix}

\section{Additional Tables and Figures}

\begin{tabular}{|c|c|c|c|}
\hline \multicolumn{4}{|c|}{ Table A1: Country-Specific Parameter Values } \\
\hline & EUR & SP & \\
\hline$j$ & 0.12 & 0.143 & Weight of Housing in Utility Function \\
\hline$k$ & 0.68 & 0.8 & Average loan-to-value ratio \\
\hline$\alpha$ & 0.35 & 0.75 & Degree of variability of interest rate \\
\hline$n$ & 0.90 & 0.10 & Country size \\
\hline
\end{tabular}

\begin{tabular}{|c|c|c|}
\hline \multicolumn{3}{|c|}{ Table A2: Common Parameter Values } \\
\hline \hline$\beta$ & .99 & Discount Factor for Savers \\
\hline$\widetilde{\beta}$ & .98 & Discount Factor for Savers \\
\hline$\eta$ & 2 & Parameter associated with labor elasticity \\
\hline$\gamma$ & .70 & Labor-Income share for savers \\
\hline$\varepsilon$ & 6 & Elasticity of substitution among intermediate goods \\
\hline $1-\nu$ & 2 & Labor elasticity of substitution across sectors \\
\hline$\rho$ & 0.8 & Interest-rate smoothing in Taylor rule \\
\hline$\phi_{\pi}$ & .5 & Inflation Parameter in Taylor rule \\
\hline$\sigma_{\epsilon}$ & 0.29 & Monetary shock standard error \\
\hline$\rho_{\xi}$ & 0.9 & Technology shock persistence \\
\hline
\end{tabular}




\begin{tabular}{l|c|c}
\multicolumn{3}{c}{ Loan-to-value ratios } \\
\hline Country & Average (in \%) & Maximum (in \%) \\
\hline Belgium & 83 & 125 \\
Denmark & 80 & 80 \\
Germany & 67 & 80 \\
Spain & 80 & 100 \\
France & 67 & 100 \\
Ireland & 66 & 95 \\
Italy & 55 & 80 \\
Netherlands & 95 & 125 \\
Austria & 60 & - \\
Portugal & 83 & 90 \\
Finland & 75 & 75 \\
United Kingdom & 69 & 110 \\
\hline \hline
\end{tabular}

Source: Finpolconsult, Bank of Lithuania.

Table A3: Loan-to-value ratios

\begin{tabular}{|c|c|}
\hline \multicolumn{2}{|c|}{ Fixed-rate vs. floating rate systems } \\
\hline Land & Rate adjustment (percentage of new business) * \\
\hline Belgium & $F(75 \%), M(18 \%), V(6 \%)$ \\
\hline Denmark & $F(75 \%), M(10 \%), V(15 \%)$ \\
\hline Germany & Mainly $\mathrm{F}$ and $\mathrm{M}$ \\
\hline Greece & $F(5 \%), M(15 \%), V(80 \%)$ \\
\hline Spain & $V$ (more than $75 \%)$ \\
\hline France & $F / M / O(88 \%), V(14 \%)$ \\
\hline Ireland & $V(70 \%)$, otherwise mainly $M$ \\
\hline Italy & $F(28 \%)$ \\
\hline Luxembourg & $V(90 \%)$ \\
\hline Netherlands & $F(74 \%), M(18 \%), V(7 \%)$ \\
\hline Austria & $F(75 \%) . V(25 \%)$ \\
\hline Portugal & Mainly $\mathrm{V}$ \\
\hline Finland & $F(2 \%), \vee 97 \%), \circ(1 \%)$ \\
\hline United Kingdom & $V(72 \%), M(28 \%)$ \\
\hline \multicolumn{2}{|c|}{$\begin{array}{l}\text { Fixed }(F) \text { : interest rate fixed for more than five years or until final maturity. } \\
\text { Mixed }(M) \text { : interest rate fixed for one to five years: } \\
\text { Variable }(V) \text { : interest rate renegotiable after one year or tied to market rates } \\
\text { Other }(O) \quad \text { or adjustment at the lender's discretion }\end{array}$} \\
\hline
\end{tabular}

Table A4: Fixed and variable rates 


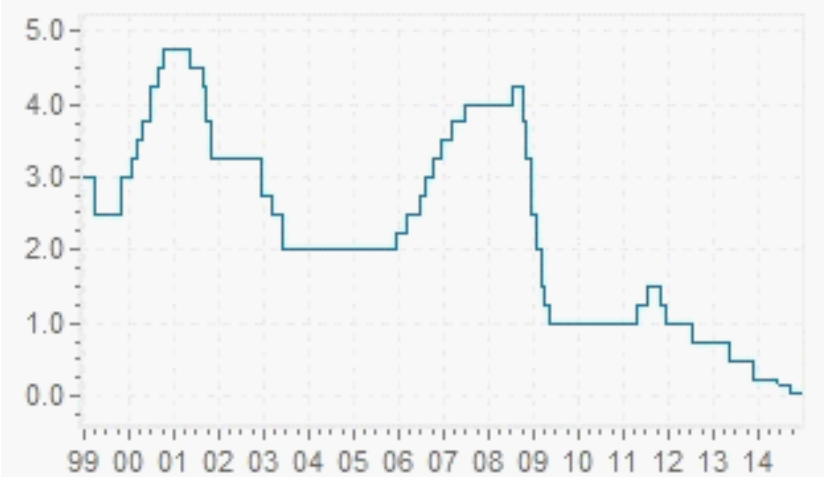

Figure A1: Interest rates in Spain (Source Bank of Spain)

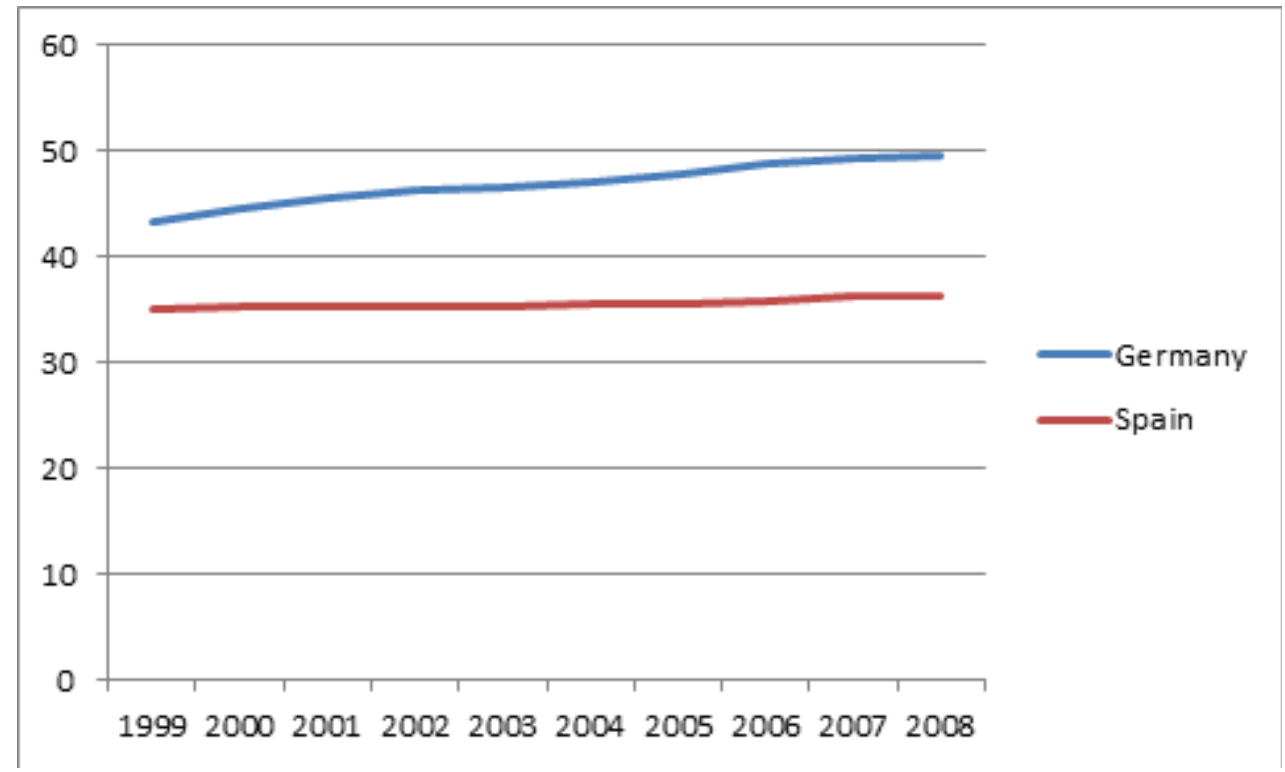

Figure A2: GDP per hour worked USD, constant prices, 2005 PPPs (Source: OECD Productivity database) 


\section{References}

[1] Akin, O., Montalvo, J., García Villar, L., Peydró, J-L. and Raya, J., (2014), "The real estate and credit bubble: evidence from Spain," SERIEs, Spanish Economic Association, 5 (2), pp. 223-243

[2] Andrés, J., Arce, O., (2008), Banking Competition, Housing Prices and Macroeconomic Stability, Bank of Spain Working Paper, 0830

[3] Andres, J., Arce, O., Thomas, C., (2013), "Banking Competition, Collateral Constraints, and Optimal Monetary Policy," Journal of Money, Credit and Banking - Supplement to Vol 45, No 2

[4] Aspachs, O., Rabanal, P., (2010), "The Drivers of Housing Prices in Spain," SERIEs, 1 (1), 101-130

[5] Benigno, P., Woodford, M., (2008), Linear-Quadratic Approximation of Optimal Policy Problems, mimeo

[6] Claessens, S., M.A. Kose and M.E. Terrones (2011): "How Do Business and Financial Cycles Interact?," IMF Working Paper, No 11/88

[7] Diemer, M. and Vollmer, U. (2015) What makes banking crisis resolution difficult? Lessons from Japan and the Nordic Countries. Eurasian Economic Review, pp. 1-27

[8] Domeij, D., Flodén, M., (2006), "The Labor-Supply Elasticity and Borrowing Constraints: Why Estimates are Biased", Review of Economic Dynamics, 9, 242-262

[9] Fernandez-Villaverde, J., Garicano, L., Santos, T., (2013). Political credit cycles: the case of the Eurozone. J. Econ. Perspect. 27,145-166

[10] Funke, M., Paetz, M., (2012), A DSGE-Based Assessment of Nonlinear Loan-to-Value Policies: Evidence from Hong Kong, BOFIT Discussion Paper No. 11/2012

[11] Gilchrist, S., Hairault, J., Kempf, H., (2002), Monetary Policy and the Financial Accelerator in a Monetary Union, ECB Working Paper, 175

[12] Horvath, M., (2000), "Sectoral Shocks and Aggregate Fluctuations", Journal of Monetary Economics, 45 (1), pp. 69-106.

[13] Iacoviello, M., (2005), "House Prices, Borrowing Constraints and Monetary Policy in the Business Cycle", American Economic Review, 95 (3), 739-764 
[14] Iacoviello, M., Neri, S., (2010), "Housing Market Spillovers: Evidence from an estimated DSGE Model", American Economic Journal: Macroeconomics, American Economic Association, 2 (2), 125-64

[15] Iacoviello, M., Smets, F., (2006), House Prices and the Transmission Mechanism in the Euro Area: Theory and Evidence from a Monetary Union Model, mimeo

[16] IMF, (2008), World Economic Outlook April 2008, International Monetary Fund

[17] In 't Veld, J., Kollmann, R., Pataracchia, B., Ratto, M., and Roeger, W. (2014). International capital flows and the boom-bust cycle in Spain. Journal of International Money and Finance. 48, $314-335$.

[18] Jeanne, O. and A. Korinek, (2014), "Macroprudential Policy beyond Banking Regulation," Financial Stability Review, Banque de France, No 18, April, pp. 163-170.

[19] Jiménez, G. and J. Saurina (2006): "Credit cycles, credit risk, and prudential regulation," International Journal of Central Banking, $\mathrm{N}^{o}$ 2, Vol. 2, pp. 65-98

[20] Kannan, P., Rabanal, P., Scott, A., (2012), "Monetary and Macroprudential Policy Rules in a Model with House Price Booms", The B.E. Journal of Macroeconomics, Contributions, 12 (1)

[21] McCallum, B., (2001), "Should Monetary Policy Respond Strongly To Output Gaps?," American Economic Review, 91(2), 258-262

[22] Mendicino, C., Pescatori, A., (2007), Credit Frictions, Housing Prices and Optimal Monetary Policy Rules, mimeo

[23] Monacelli, T., (2006), "Optimal Monetary Policy with Collateralized Household Debt and Borrowing Constraint," in conference proceedings "Monetary Policy and Asset Prices" edited by J. Campbell.

[24] Monacelli, T., (2009), "New Keynesian Models, Durable Goods, and Collateral Constraints," Journal of Monetary Economics 56, 242-254

[25] Mora-Sanguinetti, J. S. and A. Fuentes (2012), "An Analysis of Productivity Performance in Spain Before and During the Crisis: Exploring the Role of Institutions", OECD Economics Department Working Papers, No. 973, OECD Publishing. DOI: 10.1787/5k9777lqshs5-en 
[26] Moro, A., Nuño, G. (2012) Does total-factor productivity drive housing prices? A growth-accounting exercise for four countries Economics Letters 115, 221-224

[27] Peeters, M. and den Reijer, A. (2014) Coordination versus flexibility in wage formation: a focus on the nominal wage impact of productivity in Germany, Greece, Ireland, Portugal, Spain and the United States, Applied Economics, 46:7, 698-714

[28] Rubio, M., (2011), "Fixed- and Variable-Rate Mortgages, Business Cycles, and Monetary Policy," Journal of Money, Credit and Banking, 43 (4), pp. 657-688

[29] Rubio, M., (2014), "Housing Market Heterogeneity in a Monetary Union," Journal of International Money and Finance, 40, pp. 163-184

[30] Rubio, M., Carrasco-Gallego, J.A., (2014), "Macroprudential and Monetary Policies: Implications for Financial Stability and Welfare", Journal of Banking and Finance, 49, pp. 326-336

[31] Saurina, J., (2011), Countercyclical macroprudential tools. National Institute Economic Review, 216 (1), pp. 16-28.

[32] Schmitt-Grohe, S., Uribe, M., (2004), "Solving Dynamic General Equilibrium Models Using a Second-Order Approximation to the Policy Function," Journal of Economic Dynamics and Control, 28, pp. 755-775

[33] Shirai, S. (2014) Japan's monetary policy in a challenging environment. Eurasian Economic Review, Vol. 4 (1), pp 3-24 